\title{
Title: Bicycles, 'barrows and donkeys: pinning a tale on the Irish border
}

Author name: Dr Peter Leary

Email: peter.leary@history.ox.ac.uk

Address: St Hugh's College, St Margaret's Road, Oxford OX2 6LE

Biography: Peter Leary is the Canon Murray Fellow in Irish History at the University of Oxford. He studied at Goldsmiths', University of London and the University of Ulster at Magee in Derry, before completing a PhD in Irish History at Queen's University Belfast. His first book, Unapproved routes: histories of the Irish border, 1922-72 (Oxford: Oxford University Press, 2016), was awarded the Donald Murphy Prize for Distinguished First Book by the American Conference for Irish Studies, and shortlisted for the Royal Historical Society's Whitfield Prize. 


\section{Bicycles, 'barrows and donkeys: pinning a tale on the Irish border}

In November 1933, a journalist from Dublin cautiously broached the question of smuggling with a farmer - named only as Barney - who lived adjacent to the Irish border. Perhaps it 'wouldn't do to talk about it in public'?

'Talk about it...Sure the whole country's doin' nothin' else. There never was as much crack around here as far back as I [can] remember'. ${ }^{1}$

By that time smuggling had been a feature of the Irish border for a decade. The border itself had been created by the Government of Ireland Act 1920 and the Anglo-Irish Treaty of 1921. These followed a prolonged political, and shorter military struggle over the constitutional relationship between Ireland and Britain, during which, a pro-British Protestant minority concentrated in the northeast had been mobilised in opposition to Ireland's nationalist and largely Catholic majority. Partition produced both Northern Ireland, a self-governing region within the diminished United Kingdom, and what was then known as the Irish Free State, a reluctant dominion of the British Empire. ${ }^{2}$

The partition line was based on county boundaries that had been in place since the late sixteenth and early seventeenth centuries. Although in some cases these corresponded to much older fault lines associated with pre-conquest Gaelic powers, they had long held little social or economic significance and frequently violated the micro-boundaries of everyday life. The new border divided houses, villages, communities, farms and fields. Initially it was expected that these problems would be resolved by the Irish Boundary Commission provided for in the Anglo-Irish Treaty. Although it was established in 1924, when that Commission collapsed in failure a year later, all of these anomalies remained. Since then, the 
Irish border has been a site of conflict between communities as well as states, including intermittent periods of violence.

In her book, Prejudice and tolerance in Ulster, first published in 1972, anthropologist Rosemary Harris described a local smuggling operation 'whose exploits, [though looked down upon by the "respectable", and] the bane of the sergeant's life, were delightedly recounted by most of the rest of [the] inhabitants.'3 Almost forty years separates these two accounts but they also bracket in several ways the 'golden age' of smuggling along the Irish border. After that date the border began, on the one hand, to dissolve as an economic divide through the lengthy and, until recently, apparently irreversible process of integration begun by British and Irish accession to what is now known as the European Union, on 1 January 1973. On the other hand, and more dramatically, militarisation - the longterm closure of cross-border roads and construction of fortifications - transformed the border physically and psychologically for many.

The period in between - roughly the 1930s until the 1970s - is one that many people can still recall first-hand. Smuggling in Ireland continues today; fuel, for instance, is brought across and laundered. But for now at least these are, more or less, sophisticated criminal operations, sometimes with real, claimed or imagined paramilitary connections, and in terms of depth and breadth of numbers of people involved, a shadow of what once was, and occupying a very different relationship to border communities at large. Yet if direct involvement in smuggling itself is no longer a significant aspect of life, for most, on the Irish border, many of the stories and tales to which it gave rise are still alive and well.

This article has its origins in my research into one such story. It is divided into three main sections. The first explains the story in the context of the history of 
the Irish border during this period. The second locates it within Irish folklore traditions, while the third section seeks to discover its possible origins in similar tales found outside Ireland.

\section{Local legend}

The story in question concerns a man (always a man) who crossed the border daily, either on a bicycle or wheeling a wheelbarrow, and usually carrying some sort of load; hay, turf, potatoes or vegetables. These goods fell into the category of 'exempt farm produce': local products that farmers and their servants were allowed to take across. ${ }^{4}$ But in the story - for whatever reason - the customs officials were unconvinced, and subjected the traveller to regular searches.

That they might have taken such a view would not have been surprising. Using non-dutiable cargo as a screen to conceal smuggled goods was an early trick. On 1 April 1923 control of Irish customs and excise was transferred from London to Dublin with tariffs immediately applied to a range of merchandise. While smuggling started a short time later, for the first decade after partition it remained a small scale and relatively marginal pursuit. As well as a majority of farm produce, bread and other daily items remained exempt from duty; boots, shoes and clothing could be worn across; while even small quantities of tobacco and strong drink were permitted for consumption 'on the journey. ${ }^{5}$ Generally, manufactured goods from the more industrialised economies of Britain and Northern Ireland, went south.

The very first smuggling case to come before the Southern courts was that of Lawrence Hoey, a small shopkeeper of Bridge Street, Dundalk, who appeared on Friday 15 June 1923, having been apprehended two weeks earlier while driving 
his pony and loaded cart. ${ }^{6}$ When Hoey was stopped by a customs patrol, near the Carrickarnon border crossing, he explained that he had been delayed in the nearby Northern town of Newry, and produced documentation stating that he had in his possession 'a case of fruit, a case of soap, two cases of apples, and two cases of oranges.' At that time, all of this would have been perfectly legal, except that inside a container marked 'Lux', a false bottom masked 'two or three pounds of cigarettes', while another container, labelled "'Lifebuoy soap" was found to be filled with' the same product. Concealed in the fruit was '8lbs of hard confectionary' ${ }^{7}$

This may have been the first, but was very far from the last offence of its type. In October 1923, for instance, Edith Coulson, from Magheraveely, County Fermanagh, 'a young girl of respectable appearance' was convicted at Clones in County Monaghan, of smuggling 1,800 cigarettes 'concealed under some eggs in a box. ${ }^{8}$ Returning to the story, anyone who crossed the border daily - no matter how ostensibly innocent they might be - was liable to be stopped and searched and questioned. And so it goes.

Certain that he was a smuggler (a charge that he would neither confirm nor deny), the meticulous officials riffled through his hay, turned over his turf or emptied out his sacks of potatoes. Dogged as they were, they could not catch him out. As it is told, this ritual continues until, some change of circumstance - either the man ceases to make his trips, or more often, one of the officers retires, and on the day of retirement, or at some later stage, asks to be put out of his misery; 'what was it that you were up to all those years?'

'Smuggling wheelbarrows'; or 'bicycles,' as the case may be. 
It is difficult to quantify the popularity of this joke or anecdote. It crops up in history books, local and oral histories, and recently featured in the song 'No train to Cavan' by folk-singer Lisa O'Neill. ${ }^{9}$ There are striking continuities in the story, but it also changes with the telling. As well as from wheelbarrows to bicycles, oftentimes, through scraps of local detail, it is rooted in a particular place and time.

In O'Neill's lyric, the wheelbarrows go south, 'from land to land,' and smuggling is presented as having offered a limited solace amid the isolation and poor infrastructure in her native border county. ${ }^{10}$ This rendering echoes the first version that I encountered - as a child by my own grandfather - according to whom the smuggler was wheeling his "barrow" south, across the old railway bridge at the nearby village of Blacklion.

In contrast, Bryce Evans, while researching his history of Ireland during the Second World War, heard another variant of what he calls this 'popular myth' from Pat Masterson of County Leitrim. There, the bicycles were northward bound, and the easing of restrictions at the end of hostilities provided the occasion for the secret to be revealed. ${ }^{11}$ More recently, when map-maker and writer Garrett Carr travelled the border by foot and canoe, he was told a version in which the bicycle smuggler was leaving Northern Ireland. ${ }^{12}$

The War marked the second of two successive waves in which scale of smuggling mushroomed on the Irish border. The first, which provided the backdrop to the interview referred to at the beginning of this article, began in 1932, when the international turn to protectionism characteristic of the Great Depression was amplified by the election of a new government in Dublin. This Fianna Fáil, administration led by Éamon de Valera was more vocal than its predecessor in its 
commitment to political and economic autonomy, and specifically promised to withhold 'land annuities' demanded by Britain. ${ }^{13}$ In response, the British government imposed punitive tariffs of twenty percent, soon rising to forty percent, on imports of livestock from the Free State. ${ }^{14}$ By 1934 cattle duty amounted to something between sixty-eight and eighty-eight percent of an animal's value depending on its age. ${ }^{15}$ In an effort to strike back, Dublin imposed its own special duties on British goods including coal. ${ }^{16}$

The resultant price differential spurred an explosion of smuggling activity. Before long the price of a calf sold for as little as $£ 16$ on the Southern side rose to $£ 24$ once it was smuggled across. ${ }^{17}$ One letter, written from Armagh to the Northern Ireland ministry, complained of being unable to sleep owing to the noise of cattle accompanied by 'strange drivers that had to enquire the way'. ${ }^{18}$ Those involved soon acquired legendary status. Stories of smuggling escapades began to circulate - and it was in search of such, that the Dublin reporter made her cautious enquires. Brazen enough, Barney was happy to tell how it might be done:

Some time in the night they get an ould sow, or some animal that's bound to make a lot of noise... They start drivin' the sow across the Border; the police hears the commotion and the whole force rushes to the place to seize the sow, and try and catch the drivers. While this diversion is goin' on the other boys get a nice wee lot of beasts across. ${ }^{19}$

The 'Economic war' was formally ended in 1938, having gradually fizzled out from 1935 as a result of successive 'Coal-Cattle pacts. ${ }^{20}$ According to these agreements Dublin and London both agreed to purchase equal values of the other's produce.$^{21}$ But, not least as a consequence of the outbreak of the Second World War the following year, the 'crack' - as Barney put it - was set to continue.

In keeping with Masterson's version of the tale, during the War bicycles were, it seems, smuggled South to North; although bicycle tyres went the other 
way. They were also especially associated with smuggling. Partly, this arose from restrictions on the use of border crossings. The introduction of customs controls was accompanied by agreements between London and Dublin which divided border roads into three types. 'Approved' crossings, of which there were sixteen, were those equipped with customs facilities, and the only routes by which dutiable goods - including motor vehicles - could legally be brought over. The bulk of the remainder - approximately 150 in total - were classed as unapproved. These roads could be used by persons who were not carrying taxable items, provided they travelled 'by foot, cycle or horse drawn vehicle.' Officially, the only exemption to this was a small number of local doctors, vets and clergy, who were issued with permits allowing them to travel unapproved crossings by car. ${ }^{22}$ Unofficially, permission was sometimes also granted for funerals. ${ }^{23}$

There also existed a small number of 'concession' roads. These, were otherwise unapproved routes, that linked either two places in the South or two places in the North, but passed through the other jurisdiction on the way. The 'concession' that was granted allowed through traffic to transit South-to-South or North-to-North. ${ }^{24}$ Initially agreed on an ad hoc basis, but later formalised in some instances, ${ }^{25}$ such arrangements were fragile. The Lettercran road, which crosses the border five times between Castlederg and Pettigo, 'enjoyed a "neutral" status until 1932 when..., this ... was withdrawn by the British authorities. ${ }^{.26}$

As the vast majority of border crossings were unapproved, bicycles were a legitimate way by which people could travel over; faster than foot, and cheaper than a horse and cart - which was liable to be seized if caught with contraband. In addition, one could travel out of hours, as unlike cars, they did not need to be stamped in or out. They were also the principal vehicles available to young 
people, the rural poor and particularly women who, unlike in the story (in terms of numbers at least), dominated smuggling during the War. Shortages of milk, eggs, sugar, tea and other household goods directly impacted on many women's work. ${ }^{27}$ The lack of adequate numbers of women employed by the customs services also made life easier for female smugglers who could conceal small quantities with less risk than men of being searched. White flour and white bread, for instance, became highly prized commodities on the Southern side. By October 1942 the Royal Ulster Constabulary (RUC) at the Northern border village of Roslea, had accumulated a 'lorry-load of pedal bicycles, mostly ladies...seized from white bread smugglers'. ${ }^{28}$

But despite this strong connection, there are problems with this version. Evans rightly notes, that the Northern authorities were alert to bicycle smuggling as a potential problem, and took measures to prevent it. ${ }^{29}$ It was also an anomaly of the war years, when rationing and scarcity had a bigger pull than price or profit, that both sets of authorities were more concerned about what was going out than coming in; although the bread was going South, it was at Roslea, and by the RUC, that the bicycles had been seized. Although it has a ring of truth, the story doesn't quite fit. But if Pat Masterson had it wrong, it might have been the Southern customs service, or maybe, it was 'barrows' after all.

\section{$\underline{\text { A telling tale }}$}

Widespread contraband activity produced its own smuggling lore, much of which is still extant. Often blurring the boundaries between oral history - accounts of direct and personal experience - and folklore; typically, these tales involve a mixture of excitement, danger and daring - cutting close shaves with razor sharp wits. 
Folklorist Emer Ní Cheallaigh suggests that 'the overriding treatment' of smuggling 'is light-hearted and comical.' ${ }^{30}$ Sometimes this humour, she argues, may have been didactic, supplying 'other smugglers with instructions on how to locate commodities, transport smuggled goods, and, very importantly, evade capture.'31 The single, well-known story of an ingenious customs man who invited a woman to sit beside the fire for long enough for the butter she had concealed to melt and trickle down her legs, ${ }^{32}$ is one of few in which a clever official gets the better of his antagonist. As these examples illustrate, more often, the comedic boot is on the other foot:

When returning home from the Northern Ireland village of Belcoo, a woman would always buy the News of the World and place it prominently on her shopping where it could be seen. That paper was banned in the South and, on spying the offending item, the local customs officer - a well-known prude - would immediately take it behind the hut to burn. While he was occupied, her sisters and friends would rush across with their baskets filled with smuggled goods.

When a young man who was carrying a large sack of smuggled flour, he spotted a patrol coming towards him on the road. Thinking quickly, he threw the sack against the ditch and jumped on top of it. Seeing him in the dark, and assuming that he was with a young woman, the customs men were too embarrassed to stop. ${ }^{33}$

Others, of course, are less light-hearted; recalling want, necessity and the potential price of discovery - heavy fines and even imprisonment. ${ }^{34}$ Some still are tinged with resentment; against the authorities in general, frequently individual customs officers, or indeed the border itself. ${ }^{35}$ Brian Dooley, from Inniskeen in County Monaghan, recalls his father losing a ham: 'there wasn't money to buy 
another ham, but I doubt if that ham was handed in and put up for sale by the customs official. It greased some man's plate for Christmas, but it didn't get to the right place. ${ }^{36}$

Songs collected by the Irish Folklore Commission as early as the late 1930s range similarly, from humorous celebrations of the smugglers' ingenuity to lamentation of the powerlessness and poverty that drove participation in the trade. An untitled verse by James Stevenson from Skerriff in County Armagh recalls his prosecution for smuggling a cow: 'Last winter all our little ones,/ Were Lying sick in bed,/ For want of milk, I do believe,/ By now they might be dead.'37

In contrast, 'Smugglin' over the Border', collected in County Monaghan, marries contraband and comedy romance as bachelor Ned Parra Tharlaigh, is 'smuggled' across 'by an unapproved route' to be matched with a young woman from the other side of the boundary. ${ }^{38}$ Recorded elsewhere, 'The Jolly Smuggler' from County Donegal, uses illegally imported yeast in the illicit distillation of poteen in mocking defiance of 'Civic Guards [Irish police] from Kerrykeel to Muff.'39 If tears offer one possible response to inequities of wealth and power, then laughter has often afforded another. James C. Scott argues in Weapons of the weak, jokes, folklore, songs, and proverbs form a subculture fashioned from experience that offers signals as to the degree of popular acceptance of 'the social order propagated by elites. ${ }^{40}$ For Sigmund Freud, jokes and humorous anecdotes in particular 'bribe the listener . . . into taking our side,' often in antagonism to institutions, or persons 'representative of . . . institutions' ${ }^{41}$ Geographer Patrick Duffy, who grew up in the Irish borderlands, likewise described smuggling tales and songs poking fun at customs officials as "cutting the border down to size, representing local victories' over the state and its agents. ${ }^{42}$ 
One effect of such stories was to foster a self-image of border communities as what Henry Glassie has called 'a terrain of wits'. Ray Cashman has observed that, 'One aspect of local identity is [the belief] that, in contrast to...disadvantage and marginality... [border areas are], always [have] been, and always will be, home to sly, droll, and quick-thinking characters.' 'Portrayed in personal experience narratives and anecdotes', Cashman continues, 'is the...form of wit embodied by the smuggler who either outsmarts the police and customs officials or slips away to exploit the artificial border, marginality itself, another day. ${ }^{43}$

At other times (and especially for outsiders), it is a region also with its own nightmarish counterpart - and image of ancient quarrels, close-knit semi-tribal places, where no one talks and nothing ever changes. Following an ill-fated Republican raid on an RUC barracks in Rosslea in November 1955, an Irish Times reporter who visited the nearby Monaghan side, described a sinister "'poteen tradition" - police and Customs men [were] anathema with the local populace' at 'one of the best places for smugglers to get across.' 44

In both satirising and defeating authority through deception, the bicycle or wheelbarrow smuggler assumes the readily identifiable qualities of a trickster, an archetype common to folklore and myth around the world. Whereas many, and at certain times most, of those involved in contraband in twentieth-century Ireland were women, the trickster - with few exceptions - is, like the smuggler in this story, almost always male. ${ }^{45}$ Often described metaphorically as border dwellers and boundary-crossers, ${ }^{46}$ and ranging from cunning animals to demi-gods, ${ }^{47}$ the trickster is typically an underdog or liminal figure capable of moving between states - here in the conventional political sense, but more often earth and air, land and water, or the realms of the living and dead or sacred and profane. Exploiting 
that ambiguity, tricksters are typically practitioners of disguise, shapeshifters, and the bearers of simple if concealed truths, who bring disorder and confusion by upending (albeit usually temporarily) established hierarchies and behavioral norms. 'Because he lacks the strength and integrity to impose his will on a hostile world,' writes Harold Scheub, 'he adapts himself to diverse situations...inventing clever ruses, or wearing a variety of masks. ${ }^{48}$

Irish tricksters have been identified in medieval myths and folk-drama and customs such as mummers' plays. They can be found too in local religious cultures including the veneration of west Ulster patron saint, 'Colm Cille: the boisterous, irreverent, endearingly imperfect character of oral tradition'. ${ }^{49}$ Trickster traits are also linked to two classes of figure associated with preceding periods of Irish history, both of which also display some similarity to the twentieth-century smuggler.

Taking them in reverse chronological order, the first and most obvious of these is the sea-faring smuggler, most prominently associated with the eighteenth century as a consequence of expanding of consumption of goods such as tea and tobacco, rising duties, and a still relatively weak state and poor infrastructure throughout much of the island. ${ }^{50}$ Ireland's coastline remains littered with smugglers' rocks, coves, and caves to which local stories are attached.

In one example from Crookhaven in County Cork, a smuggler by the name of Daniel Coughlan was returning from Amsterdam at night with tobacco and brandy. Pursued by a revenue cutter he extinguished his ship's lantern before transporting it in a small craft to a nearby rock. There, he placed the lamp and lit it again. While 'English men' kept their eyes on the light, convinced that they still had 
him in their sight, Coughlan returned to his ship and sailed in total darkness into harbour. ${ }^{51}$

The echoes are even clearer in the case of Seán de Barra (or Barry) of Kinsale, a 'noted smuggler' in the years before 'the long war between Napoleon and the English.' According to one account, 'the revenue cutters knew that Barry was smuggling, but they never caught him in the act'. In one instance he was hailed by a patrol while on route to France with an innocent cargo of potatoes. Suspecting that Barry would return with contraband, the English captain lay in wait. Before long he was surprised when, instead of returning under cover of fog as usual, the smuggler's ship approached in plain view. In an unexpected move, the smuggler hailed the excise men to seek assistance explaining that his whole crew was laid up with fever. Alarmed at the prospect of contagion, the cutter retreated allowing Barry enough time to land his illicit cargo and have it spirited away by horses. ${ }^{52}$

The second set of pseudo-historical Irishmen that arguably bear some familial resemblance to the cross-border smuggler, are the seventeenth-century outlaws known as Tories or Rapparees. Loosely based on real figures but long since fictionalised in popular print and storytelling, these were bandits or 'noble robbers' of a type common to agrarian folklore..$^{53}$ In Ireland, they were typically Catholics, frequently cast as dispossessed former landowners of genteel birth, and often drawn from the remnants of defeated Gaelic or Jacobite armies. ${ }^{54}$

By some way the most famous of these Tories is Redmond O'Hanlon from what are now the borderlands of south Armagh. In common with many international border regions, long before partition, this area had been a frontier zone. Squeezed first between the Pale - the principal sphere of medieval English 
influence surrounding Dublin - and Gaelic Ulster, dominated by the powerful O'Neills, it later served as an interface between the Protestant dominated northeast (colonised from Scotland and England during the Plantation of Ulster), and the Catholic south and west. ${ }^{55}$

Redmond O'Hanlon shared his essential characteristics as well as his initials with the English Robin Hood, taking from the rich and not the poor categories which in south Ulster had come to carry undertones of ethnicity and religion. His reputed escapades include reversing 'his horse shoes to confuse his pursuers' and 'him and his gang using reversible jackets [which] when turned inside out they became the red coats of the army, and were used on many occasions to outwit the authorities and unsuspecting travellers. ${ }^{56}$

According to myth, O'Hanlon regularly exploited his cunning to move between the official world of the authorities and settlers - town, the law, and established Church - and that of the native Irish and the untamed hills in which he lived. In one account, he used a forged letter to gain access to his enemy's stronghold and rescue an accomplice's sweetheart. In another, disguised as an old Protestant minister, he requested and received protection from a party of 'English' soldiers. Once safely out of town, he signalled to his men and took the soldiers captive. ${ }^{57}$

Accounts of O'Hanlon and other Tories 'taxing' travelling strangers on the roadside might easily be seen as anticipating the later activities of the customs men. Although, as with smuggling, it is most often the outlaw who gets the upper hand, they too could be on the receiving end of trickery. A young man travelling north to collect a debt of $£ 100$ at Newry, filled his purse with copper coins before he left. Encountering O'Hanlon on the road, he pretended not to recognise the 
outlaw and (apparently naïvely), explained to him the purpose of his trip. The highwayman awaited the youth's return and when he approached issued the order: 'Stand and deliver.'

'If you desire it,' replied the traveler feigning surprise, 'then you can follow it,' throwing the purse as far as he could into a bog beside the road. With that, he sent O'Hanlon after the bag containing only small change while making his own escape along with the larger sum. ${ }^{58}$

Folktales have been distinguished from legends, in that, while the latter are believed to be true, the former primarily serve a function within a certain social context. ${ }^{59}$ 'If bandits and poachers are made into folkheroes,' writes James C. Scott, 'we can infer that transgressions of elite codes evoke a vicarious admiration.' 60 The elevation of smugglers - by land or sea - and of outlaws from an earlier period offer insights into rural class relations that in Ireland have been intertwined with religious and ethnic identities. It was these same antagonisms that would coalesce in the competing national projects that were ultimately materialised at the border.

Whether educative, subversive or simply entertaining, the survival and spread of funny stories, demands that they be heard as well as that they are told. ${ }^{61}$ Whatever its origins, the popularity of this anecdote in Ireland indicates its resonance with common memories and experiences. It suggests also a ready audience for whom, some at least of those outside the law had long been celebrated. 


\section{Global fable}

Although the account of a man smuggling wheelbarrows or bicycles clearly fitted neatly with the experiences and popular culture of Irish border areas, this is not the only place where similar stories are found. In 2001 a woman named Mary Kate from Killesher in County Fermanagh in Northern Ireland, shared this tale during a local oral history project, conducted with by then elderly female border residents. When extracts from the interviews were published as a book, the editor added an explanatory note: 'This is a more recent Irish version of a very old Arabic folk tale of Mulla Nasrudin smuggling donkeys.' ${ }^{62}$ The source for that claim appears to be The Sufis published in 1964:

[Mulla] Nasrudin used to take his donkey across a frontier every day, with the panniers loaded with straw. Since he admitted to being a smuggler when he trudged home every night, the frontier guards searched him again and again. They searched his person, sifted the straw, steeped it in water, even burned it from time to time. Meanwhile he was becoming visibly more prosperous.

Then he retired and went to live in another country. Here one of the customs officers met him, years later.

"You can tell me now, Nasrudin," he said. "Whatever was it that you were smuggling, when we could never catch you out?

"Donkeys," said Nasrudin. ${ }^{63}$

Mulla Nasrudin, the smuggler in this story, figures in folklore through much of Asia and the Middle East. Usually a poor country-man, who typically rides a donkey rather than a horse, he reputedly lived in present-day Turkey during the thirteenth century. ${ }^{64} \mathrm{He}$ is a folk-philosopher; a wise fool and trickster whose moralistic, sometimes table-turning, parables combine a sense of fun with seemingly accidental insights.

Nasrudin was throwing handfuls of crumbs around his house. 'What are you doing?' someone asked him. 
'Keeping the tigers away.'

'But there are no tigers in these parts.'

'That's right. Effective, isn't it?'65

The same story, 'the smuggler', is also found in another volume, The exploits of the incomparable Mulla Nasrudin, published in 1966: 'Time and again Nasrudin passed from Persia to Greece on donkey-back. Each time he had two panniers of straw. ${ }^{\prime 66}$

It is patently possible for folk-tales to cross cultures. Several anecdotes, long attributed to Nasrudin in Turkish texts, append to alternate figures in earlier works in Arabic and other languages. Many have moved back and forth between oral traditions and manuscript. ${ }^{67}$ But this story would have made little sense in Ireland before partition in the 1920s, which suggests that these books themselves rather than direct oral transmission, might be a possible source.

Idries Shah, the author, or collector of these tales, was a kind of Guru writer, businessman and publisher - who promulgated, to his European and American followers, his own brand of Islamic Sufi mysticism. Shah also wrote about occult and esoteric thinking, which in Ireland, has tended to look west as well as east and back, unto a Gaelic past, for inspiration. ${ }^{68}$ His books appeared in the 1960s; a decade when Western fascination with 'Eastern religion' was on the rise, on the back of youth culture, television, psychedelic drugs and - much as the expansion of road and rail had earlier done for the west of Ireland - the 'hippy trail' and increased availability of air travel. ${ }^{69}$ The Sufis, includes an introduction by Robert Graves, clearly an enthusiast, whose father Alfred Perceval Graves was active in the Irish Literary Revival. In his introduction Graves compares the Sufi poets to those of 'medieval Ireland,' and wonders, if what he calls the 'Irish Musegoddess Bridget' might have 'came from the East along with the complicated 
arabesques of...Irish illumination art'. ${ }^{70}$ Another of his collections, was described by an Irish Press reviewer in 1970 as 'a collection of...Arab proverbs that could have come from Connemara or could easily travel there. ${ }^{71}$

These then, are times and places, worlds apart, that have sometimes been imagined similarly, suggestive of a surprising story about Ireland and Islam, tradition and modernity, comedy and power, and truth and lies. But there is something troubling about the Nasrudin tale. Considered historically, it has a very modern feel.

If 'hiding in plain sight' is an idea of ancient pedigree (it is really a reversal of the Horse of Troy), the same cannot be said for state boundaries. Unlike frontiers, marchlands and other older forms of boundaries, modern international borders imply a clearly delineated territorial sovereignty that is seen to have emerged in Europe following the Treaties of Westphalia in 1648. From there, it spread, displacing alternative conceptions of space and allegiance - either through colonialism directly or precipitated by its presence. The Thai monarchy, for instance, was prompted to define the borders of Siam, both on maps and on the ground, by the threat of encroachment posed by the British in Burma, and the French in what they knew as Indo-China. ${ }^{72}$

The Irish border emerged relatively late, but fully formed; in Europe, shortly after the First World War, at a time when boundary making was all the rage. It was a partition - a 'fresh cut' 73 - but followed county boundaries in place for centuries, which had been mapped with military precision by the Ordnance Survey. At almost exactly the same time, as Ireland was partitioned, the British and French colonial powers in Palestine, Lebanon and Syria - had to start essentially from scratch to 
establish the physical extent of their newly acquired possessions. This was something that their former rulers had simply never felt the need to do. ${ }^{74}$

The apparatus of borders - customs patrols and border posts - also requires some degree of stability or mutual recognition. The Irish border was certainly contested: customs stations, for one thing, were blown up in the 1920s, and burnt down in 1937 to 'welcome' George VI to Belfast. They were razed again in the 40 s and 50 s, before being repeatedly destroyed from the 1970 s onwards. But not only did the border not move as a consequence, it was also recognised by senior officials that the Republicans who attacked the huts were 'at some pains not to extend their hostilities to the people occupying them. ${ }^{75}$

Were the legend of Nasrudin to be true, then it is hard to imagine the same being said of any of the polities that he might have encountered - the early Ottoman or various Mamluk empires, the Sultanate of Rum where he reputedly lived, or the invading offspring of Genghis Khan. It is hard, at least, to imagine donkey smugglers being big concern.

There are obvious limitations, when dealing with an anecdote of this kind, to standard historiographical or biographical approaches. While in Ireland, 'the smuggler' has been anonymised, Ulrich Marzolph has argued that Nasrudin himself serves as a transnational 'crystallizing' figure, around whom stock ideas and stories 'deriving from a variety of origins' have coalesced. ${ }^{76}$ The resulting material, both written and oral, is naturally subject to further adoption, adaption and embellishment over time.

But an out of time political border is not the only problem with this account. In a 1975 article, the then eminent Edinburgh orientalist, Lawrence Paul ElwellSutton, characterised Shah's books as: 'amateurish compendia culled from...the 
shelves of the public libraries'. ${ }^{77}$ Neither of the earlier English language Nasrudin collections dating from $1884{ }^{78}$ and $1923,{ }^{79}$ contain this story nor do those that are subsequent, of which, there are several. It does, however, appear in other places.

It is possible in fact that the first print variant of this story dates from 1951. It featured in various newspapers, under the name of Erskine Johnson, a Hollywood gossip columnist, and involves a man stealing wheelbarrows from an unnamed defence establishment. ${ }^{80}$ In January 1952, in the midst of a scandal that would lead to his resignation, it was repeated to journalists by US Attorney General, J. Howard McGrath. In his telling, it becomes a Russian warehouse, and the secret was finally revealed to the guard who has been rendered harmless by his imminent departure for Siberia. 'Things,' McGrath insisted, 'are not always what they appear'. 81

Later that year, it received further prominence in the publications of Bennett Cerf:
When Juan and Evita Peron were building a luxurious retreat for themselves some miles outside of Buenos Aires they established a rigid guard around the project to prevent the stealing of valuable materials. Every day at noon, the story goes, the same workman began to appear at the exit gate with a wheelbarrow loaded with straw. The guard, convinced that there was dirty work afoot, searched the straw more carefully daily - even had it analysed to see if it possessed special chemical values - but could find nothing to substantiate his suspicion, and had to let the workman pass.

Bennett Cerf was a publisher and founder of Random House, who fancied himself a raconteur. Through his syndicated jokes column, 'Try and stop me', it appeared in various titles starting around July 1952. He also produced numerous humorous collections one of which, Good for a laugh, from 1953, also contains this anecdote. ${ }^{82}$ While this does not disprove the possibility of an older pedigree, it does pose a question of genealogy. The presence, of wheelbarrows in this story 
about theft, and of smuggling in the story about donkeys, places smuggling wheelbarrows somewhere in between.

Most of Cerf's jokes touch what were then contemporary concerns: the Cold War, Red China; Hollywood, Broadway and broadcast stars; high society, business magnates or Washington politicians. Others reflect the cultural moment in America: the power of the automobile industry, new household gadgets, the dream of a 'push-button home', and young housewives confused by dehydrated food. ${ }^{83} \mathrm{He}$ may have moved it to Argentina, but this was too good a joke to waste on South American populism. It had become a piece of Cold War propaganda. It soon popped up again as a piece of 'fake news' - contained within an otherwise serious article alleging rampant corruption within the Communist states. This time, a factory operative in Budapest was stealing wheelbarrows under the nose of a Communist Party official. ${ }^{84}$ It is a short step to post-War, but still pre-Wall, Berlin. By 1954 the story is fully formed, again in ostensibly factual accounts of life in that divided city; smuggling wheelbarrows daily past the Red border guards. ${ }^{85}$ Directly or indirectly, there is every reason to suppose that this is the Irish source.

Instead of hybridity of East and West, free love and ancient wisdom, this story appears to date from the 1950s; the homogenising influence of expanding US cultural hegemony, underpinned by high-Fordism and the post-War boom. How exactly it was smuggled into twentieth-century Ireland belongs to speculation. Assuming an American cradle, did a migrant or visitor hear or read it, and carry it over by word of mouth? Or maybe, someone clipped it from the funny papers and sent it home with a letter to friends or family. The existence of both bicycle and wheelbarrow versions suggests it might have made the journey more than once. 
The conservative post-War Western mind could call on few more menacing images than that of the 'Iron Curtain.' Why the border must be, a pamphlet issued in 1956 by the Northern Ireland government, warned that 'Communism is not the only threat to freedom.' Equating Dublin's Catholic moral censorship to that of the Soviet Union, it promised to: 'hold the bridgehead so that one day the freedom which is here in Northern Ireland, in Great Britain and in the United States will lighten the whole world.' ${ }^{86}$ After 1961, nationalists repeatedly invoked the Berlin Wall in relation to road closures, and a little over ten years later, many official crossings would begin to invoke comparison with Checkpoint Charlie. ${ }^{87}$

Yet, in Ireland, the story seems to lack that kind of pointed polemical edge. Whether the smuggler was working North to South or South to North, for instance, does not appear to be conditioned by the political allegiances of the teller. There is such a thing as 'copy-cat crime', but this one, went far and wide. As well as various parts of Eastern Europe, otherwise identical tales of theft later attached to South African diamond mines, ${ }^{88}$ and to various shipyards - including Harland and Wolff in Belfast. ${ }^{89}$ Through the 1960s it appeared and reappeared, with bicycles going from France to Italy, ${ }^{90}$ the tales of Mulla Nasrudin published in the $1960 \mathrm{~s}$ and, by 1972, both bicycles and wheelbarrows were being smuggled - or at least the tale was being told - about the border between Mexico and the United States. ${ }^{91}$ There, as in Ireland, the joke became a staple. ${ }^{92}$

That was the year that Rosemary Harris's Prejudice and tolerance in Ulster, was published. The smuggling outfit she described concerned two sets of brothers, one from each side of the political divide; a 'heartening example of Catholic/Protestant economic cooperation', in her words. The research had been conducted earlier, but the book bears the hallmarks of the Troubles that, by then, 
were already underway. ${ }^{93}$ It was a year that began with clashes all along the Irish border, amidst the latest attempt to seal the border roads. Many would remain closed for most of the following four decades. But already there were other political and economic forces at work. As early as 1968 , newspapers had started to report the 'death of a way of life'; how the old-time smuggler, playing cat and mouse on a bicycle, was being edged out by trade reform, in favour of fast cars and commercial enterprises both open and illegal. ${ }^{94}$ This is a time when smuggling, for many, was slipping into memory against a spiral of deadly violence, and the legend of a golden age of innocence, simplicity, and peace was beginning to take root.

\section{Conclusion}

Smuggling was a major part of life on the Irish border for forty years or more. The issues surrounding border roads are but one example of the isolation, disruption and marginalisation that smuggling exploited, but which, it was also an attempt to overcome. Smuggling always had its funny side, but that was coupled to danger and the difficulties out of which it arose. Heroic myths could capture something of the spirit of the trade without giving away the actual tricks and methods. Through their lasting humour, an aspect of the history of twentieth-century Ireland has been partially preserved. But they also serve to anaesthetise against more complex and painful memories. Through smuggling stories border communities expressed their animosity to the border and the authority it betokened - whether political opposition to partition or simply frustration with what one observer called, 'one of the worst examples of frontier bureaucracy in existence. ${ }^{95}$ 
For those involved, it could be an emboldening experience. Smuggling stories lack the appeals to magic associated with peasant powerlessness, and strike instead, the almost optimistic notes of those who might just hope 'to make up for their weakness through resourcefulness and wit. ${ }^{96}$ If this is a tale that cuts across both space and time then, so too, history and political geography cut across the otherwise unremarkable lives of people living on the border. For many, partition was a bitter experience, but those who are given lemons can sometimes turn them sweet by making lemonade.

Alison Light has recently written that "'history from below" [should not imply] a perspective removed from the wider sweep of power.'97 Gramsci saw aspects of popular culture pertaining to the 'subaltern' or popular classes, as articulating 'conceptions of the world' which, 'go against, or merely differ from,' those reflected in high culture and belonging to dominant groups. Fragmentary, and often contradictory, these world-views can combine elements received or selected from outside, and residue reflecting previous periods, as well as 'innovations, spontaneously determined by the forms and conditions of life'. ${ }^{98}$

Like folklore generally, smuggling has more often been discussed alongside rural backwardness, than modernity and social change, but who smuggled, what and when, were questions answered in response to evolving economic, political and cultural contexts and, therefore, to the various currents of conflict and tensions characteristic of Ireland at the time. The popularity of this story reflects that particular lived experience, and the ways in which it chimed with longestablished traditions of outlawry, illegality and subversion. But its presence in Ireland also speaks of movement - across permeable borders and other social boundaries, and the overlapping circuits of people, things and ideas. 
From their marginal position, people on both sides of the Irish border engaged in smuggling in order to make the most of their often-troubled situation. Buffeted, not only by the national histories of the states in which they lived, but also economic and cultural processes that increasingly, were global in extent, they drew creatively on both. Out of such circumstances were fashioned a history then, still in the making - and a memory of the past, that ameliorated their difficulties and brought laughter to their lives.

\footnotetext{
${ }^{1}$ Irish Independent, 24 Nov. 1933.

${ }^{2}$ See, Peter Leary, Unapproved routes: histories of the Irish border, 1922-72, Oxford, 2016, pp 3-7.

${ }^{3}$ Rosemary Harris, Prejudice and tolerance in Ulster: a study of neighbours and 'strangers' in a border community, Manchester, 1972, p. 184.

${ }^{4}$ W. F. Stout to S. H. E. Burley, 20 Nov. 1962 (PRONI, Closing of cross-border roads: miscellaneous correspondence and incident reports, 1957-71, Cabinet Secretariat, CAB/9/G/73/11)

${ }^{5}$ Evidence of Mr O'Golain, 19 June 1925 (The National Archives of the UK (TNA), Irish Boundary Commission (IBC), Irish Free State Customs Service, CAB 61/76, pp 11-14)

${ }^{6}$ Freemans Journal, 16 June 1923.

${ }^{7}$ Ulster Herald, 16 June 1923.

${ }^{8}$ Freemans Journal, 3 Oct. 1923.

${ }^{9}$ Lisa O'Neill, 'No train to Cavan', Youtube, (www.youtube.com/watch?v=laDgJl5QYhk) (07 Dec. 2016). The song addresses isolation and lack of infrastructure in border areas.

${ }^{10}$ Lisa O'Neill, 'No train to Cavan', Youtube, (www.youtube.com/watch?v=lqDgJl5QYhk) (20 June 2017).

${ }^{11}$ Bryce Evans, Ireland during the Second World War: farewell to Plato's Cave (Manchester, 2014), p. 100.

${ }^{12}$ Garrett Carr, The rule of the land: walking Ireland's border (London, 2017), p. 71.

${ }^{13}$ Brian Girvin, 'The republicanisation of Irish society, 1932-48' in J. R. Hill (ed.), A new history of Ireland, vii: Ireland, 1921-84, Oxford, 2003, p. 130.

${ }^{14}$ D. S. Johnson, 'Cattle smuggling on the Irish border, 1932-8', Irish economic and social history, xi, 1979, p. 44.

${ }^{15}$ David Johnson, The interwar economy in Ireland, Dublin, 1985, p. 16.

${ }^{16}$ Anglo-Celt, 3 Sept. 1932.

${ }^{17}$ Catherine Nash, Lorraine Dennis and Brian Graham, 'Putting the border in place: customs regulations in the making of the Irish border, 1921-45', Journal of historical geography, xxxvi, 2010, p. 430.

${ }^{18}$ Excerpt from a letter, 7 July 1933 (Public Record Office of Northern Ireland (PRONI), Difficulties with Customs Authorities, Department of Commerce, COM/62/1/365)

${ }^{19}$ Irish Independent, 24 Nov. 1933.

${ }^{20}$ Connacht Sentinel, 8 Jan. 1935.

${ }^{21}$ Connacht Sentinel, 8 Jan. 1935.
} 
${ }^{22}$ W. F. Stout to S. H. E. Burley, 20 Nov. 1962 (PRONI, Closing of cross-border roads: miscellaneous correspondence and incident reports, 1957-71, Cabinet Secretariat, CAB/9/G/73/11)

${ }^{23}$ Memorandum in response to Dail question, 4 April 1961 (National Archives of Ireland (NAI), Parliamentary Question for answer by Minister for External Affairs, 11 April 1961, relating to spiking of roads on Leitrim-Fermanagh Border, Department of Justice, Equality and Law Reform, JUS 8/1125)

${ }^{24}$ W. F. Stout to S. H. E. Burley, 20 Nov. 1962 (PRONI, Closing of cross-border roads: miscellaneous correspondence and incident reports, 1957-71, Cabinet Secretariat, CAB/9/G/73/11)

${ }^{25}$ Note on concession roads, 9 July 1956 (NAI, Representation re. use of roads near the border by residents in Ireland, Jan 1939, Department of Foreign Affairs, 305/14/14 la)

${ }^{26}$ Report by F. H. Boland, 11 Jan. 1940 (NAI, Representation re. use of roads near the border by residents in Ireland, Jan 1939, Department of Foreign Affairs, 305/14/14 la)

${ }^{27}$ Maria Luddy, 'The problem of equality: women's activist campaigns in Ireland, 1920-40' in Thomas E. Hachey (ed.), Turning points in twentieth-century Irish history, Dublin, 2011, p. 71. ${ }^{28}$ Anglo-Celt, 25 Oct. 1941.

${ }^{29}$ Bryce Evans, Ireland during the Second World War, p. 100.

${ }^{30}$ Emer Ní Cheallaigh, "The road that runs down by the border": a study of smuggling in the oral tradition of Ireland' (M.Litt. thesis, University College Dublin, 2005), p. 20.

${ }^{31}$ Emer Ní Cheallaigh, "The road that runs down by the border": a study of smuggling in the oral tradition of Ireland' (M.Litt. thesis, University College Dublin, 2005), p. 92.

${ }^{32}$ Gilbert Denton and Tony Fahy, The Northern Ireland land boundary, 1923-92 (Belfast, 1993), p. 54. This story may have warned young women about accepting such hospitality and boosted the moral of customs officers who were usually butt of the joke.

${ }^{33}$ Both of these stories are taken from, Anita Gallagher (ed.), Rinso Days and Rainbow Nights: Women's Lives in Glenfarne, Co. Leitrim 1920-1960, Manorhamilton, 2001, pp 147-50.

${ }^{34}$ James Stevenson, Skerriff, Co. Armagh, untitled poem, 1934 (Irish Folklore Commission Schools Manuscript Collection, 942, pp 15-7)

${ }^{35}$ See, Anita Gallagher (ed.), Rinso Days and Rainbow Nights, p. 147.

${ }^{36}$ Brian Dooley, Border roads to memories and reconciliation (www.borderroadmemories.com) (26 Nov, 2014).

${ }^{37}$ NFCS 942: 15-17; James Stevenson (67), Skerriff, County Armagh. Collector: Saidee Martin, Lorg an larla, Lurganearly, Co. Monaghan, 1937-8. Teacher: E. Ní Choilldubh.

${ }^{38}$ NFCS 939: 228-32; Michael Keenan, Coravoo, Castleblaney, County Monaghan. Collector: unknown, Láithreach, Laragh, Co. Monaghan, 1935. Teacher: Mrs Duffy.

39 Jimmy McBride, Inishowen Traditional Singers' Circle, March 2012, Irish traditional music archive (www.itma.ie/digital-library/sound/iolly smuggler jimmy mcbride) (11 July 2017). ${ }^{40}$ James C. Scott, Weapons of the weak: everyday forms of peasant resistance, New Haven: Yale University Press, 1985, p. 41.

${ }^{41}$ Sigmund Freud, The joke and its relation to the unconscious (London: Penguin, 2002), p. 101, p. 106.

${ }^{42}$ Patrick J. Duffy, 'Continuity and change in the border landscapes', in The Debatable land: Ireland's border counties, edited by Brian S. Turner (Downpatrick, Co. Down: Ulster Local History Trust, 2002), pp. 20-30.

${ }^{43}$ Ray Cashman, Storytelling on the Northern Irish border: characters and community (Bloomington, IN, 2008), p. 186.

${ }^{44}$ Irish Times, 29 Nov. 1955.

${ }^{45}$ Lewis Hyde, Trickster makes this world: how disruptive imagination creates culture, Edinburgh: Canongate, 2017, pp 335-43. 
${ }^{46}$ William J. Hynes, 'Mapping the characteristics of mythic trickster: a heuristic guide' in William J. Hynes and William G. Doty (eds), Mythical trickster figures: contours, contexts and criticisms, Tuscaloosa, Ala and London: University of Alabama Press, 1993, pp33-45. Lewis Hyde, Trickster makes this world: how disruptive imagination creates culture, Edinburgh: Canongate, 2017, p. 7. ${ }^{47}$ Alan Harrison, The Irish trickster, Sheffield: Sheffield Academic Press for the Folklore Society, p. 24.

${ }^{48}$ Harold Scheub, Trickster and hero: two characters in the oral and written traditions of the world, Madison, Wis.: University of Wisconsin Press, 2012, p. 6.

${ }^{49}$ Alan Harrison, The Irish trickster, pp 22-3; pp 87-97. Breandán Mac Suibhne and David Dickson, 'Introduction' in Hugh Dorian (Breandán Mac Suibhne and David Dickson eds.), The outer edge of Ulster: a memoir of social life in nineteenth-century Donegal, Indiana, 2001, pp 22.

${ }^{50} \mathrm{~L}$. M. Cullen, 'The smuggling trade in Ireland in the eighteenth century' in Proceedings of the Royal Irish Academy: Archaeology, Culture, History, Literature, vol. 67, 1968/1969, pp 149-175. ${ }^{51}$ NFCS 287: 6-7; John Sullivan (60), Arduslough, County Cork. Collector: Mary Sullivan, Cruachán, An Sciobairín, 1937. Teacher: Saidhbhín Ní Bhoidbléir.

52 NFCS 320: 54-5: Séamus Breathnach, Kinsale, County Cork. Collector: unknown, Clochar na Trócaire, Ceann tSáile, 1937-8. Teacher: An tSr. De Pazzi

${ }^{53}$ Eric Hobsbawm, Bandits ( $4^{\text {th }}$ revised ed.), London, 2000, pp 47-8.

${ }^{54}$ Niall Ó Ciosáin, 'Highwaymen, Tories and Rapparees' in History Ireland, iii, vol. 1, Autumn 1993, pp 19-21.

${ }^{55}$ Patrick J. Duffy, 'Geographical perspectives on the borderlands' in Raymond Gillespie and Harold O'Sullivan (eds), The borderlands: essays on the history of the Ulster-Leinster border, Belfast: Institute of Irish Studies, The Queen's University of Belfast, 1989, pp 6-8. Eileen McMahon, 'A study of the economic, political, social and cultural dynamics of smuggling on the Monaghan border area' (MA dissertation, Queen's University Belfast, 2004), pp. 22-5.

${ }^{56}$ Stephen Dunford, The Irish highwaymen, Dublin: Merlin Publishing, 2000, p. 41.

${ }^{57}$ NFCS 947: 148-51: John Mac Donald (74), Tullaghaloyst, County Monaghan. Collector: Michael Moore, Killyfargy, Co. Monaghan, 1935. Teacher: B. Ó Mórdha

${ }^{58}$ Stephen Dunford, The Irish highwaymen, Dublin: Merlin Publishing, 2000, pp 42-3.

${ }^{59}$ Diarmuid Ó Giolláin, 'Revisiting the holy well' in Éire-Ireland, xl, Spring/Summer 2005, pp 11-41.

${ }^{60}$ James C. Scott, Weapons of the weak: everyday forms of peasant resistance, New Haven: Yale University Press, 1985, p. 41.

${ }^{61}$ As Freud suggested, 'no one can be content with having made a joke for [themselves] alone.'

Sigmund Freud, Jokes and their relation to the unconscious, London, 1960, pp 140-43.

${ }^{62}$ Anita Gallagher (ed.), Rinso Days and Rainbow Nights, p. 150.

${ }^{63}$ Idries Shah, The Sufis, London, 1964, p. 59.

${ }^{64}$ Alternative spellings and variants of his name and title include Nasreddin Hoca, Nasr al-Din Khodja, Cogia Nasr Eddin Effendi and others.

${ }^{65}$ Idries Shah, The exploits of the incomparable Mulla Nasrudin, London, 1973, p. 22.

${ }^{66}$ Idries Shah, The exploits, p. 22.

${ }^{67}$ Ulrich Marzolph, 'Timur's humorous antagonist, Nasreddin Hoca' in Oriente Moderno, Ixxvi, no. 2, 1996, pp 485-98.

${ }^{68}$ See, Roy Foster, W. B. Yeats, A Life, I: The Apprentice Mage 1865-1914, 2 vols, Oxford, 1997, i, 129-31.

${ }^{69}$ Robert Irwin, Memoirs of a Dervish: Sufis, mystics and the sixties, London, 2011, p. 209.

${ }^{70}$ Robert Graves, 'Introduction' in Idries Shah, The Sufis, London, 1964, pp xi-xiii.

${ }^{71}$ Irish Press, 14 Aug. 1970. Connemara is a mountainous and Gaelic speaking district in the west of Ireland.

${ }^{72}$ See, Thongchai Winichakul, Siam mapped: a history of the geo-body of a nation, Honolulu, 1994. 
${ }^{73}$ Brendan O'Leary, 'Analysing partition: definition, classification and explanation', Political Geography, xxvi, 2007, pp 886-908.

${ }^{74}$ Asher Kaufman, Contested frontiers in the Syria-Lebanon-Israel region: cartography, sovereignty, and conflict, Baltimore, 2014, p. 18.

${ }^{75}$ L. Petch to Philip Allen, 20 Oct. 1971 (TNA, Border between Northern Ireland and Irish Republic: Army measures to prevent illegal incursions; discussions with FCO and Home Office at Ministerial and official levels, 1971-2, CJ 4/213)

${ }^{76}$ Ulrich Marzolph, 'Persian humour in the international context' in Ruse and wit: the humorous in Arabic, Persian, and Turkish narrative, Boston. Mass., 2012, pp 33-43.

${ }^{77}$ L. P. Elwell-Sutton, 'Sufism and pseudo-Sufism' in Encounter, xliv, no. 5, 1975, pp 9-17.

${ }^{78}$ G. H. Borrow, The Turkish jester; or, The pleasantries of Cogia Nasr Eddin effendi, Ipswich, 1884.

${ }^{79}$ Henry D. Barnham, Tales of Nasr-ed-Din Khoja, London, 1923.

${ }^{80}$ Odessa American, 3 Dec. 1951.

${ }^{81}$ El Paso Herald-Post, 4 Jan. 1952.

${ }^{82}$ Bennett Cerf, Good for a laugh: a new collection of humorous tidbits and anecdotes from Aardvark to Zythum, London, 1953.

${ }^{83}$ Bennett Cerf, Good for a laugh: a new collection of humorous tidbits and anecdotes from Aardvark to Zythum, London, 1953.

${ }^{84}$ Kansas City Star, 14 July 1953.

${ }^{85}$ Sedalia Democrat, 14 Nov. 1954.

${ }^{86}$ Why the Border must be: The Northern Ireland case in brief, The Northern Ireland Government, 1956 (http://cain.ulst.ac.uk/othelem/docs/nigov56.htm) (21 Nov. 2014).

${ }^{87}$ Fermanagh Herald, 13 Nov. 1971.

${ }^{88}$ Will Fitzhugh, 'Wheelbarrows', The concord review

(http://theconcordreview.blogspot.co.uk/2010/01/there-is-old-story-about-worker-at-one.html) (17 Oct. 2014).

${ }^{89}$ Blog account of open-top bus tour, (www.ancientworlds.net/aw/Journals/Journal/355848\&caldate=2005-07-20\%2021:00:00) (17

Oct. 2014)

90 Ogden Standard-Examiner, 4 May 1964.

${ }^{91}$ Vidette-Messenger, 14 June 1972; Express and News, 21 May 1972.

${ }^{92}$ See, Daniel Boyarin, Border lines: the partition of Judaeo-Christianity, Philadelphia, 2004, p. 1.

${ }_{93}$ Rosemary Harris, Prejudice and tolerance in Ulster, pp xiii-iv.

${ }^{94}$ Daily Telegram, 10 Feb 1968.

${ }^{95}$ Typescript reminiscences of P.S. Callaghan, as radio operatior with the US Air Corps at Belleck, Co. Fermanagh during the Second World War, 1942 (PRONI, Reminiscences of P.S. Callahan, T3556)

${ }^{96}$ Diarmuid Ó Giolláin, Locating Irish folklore: tradition, modernity, identity, Cork, 2000, p. 162.

${ }^{97}$ Alison Light, Common people: the history of an English family, London, 2014, p. 178.

${ }^{98}$ Cited in Diarmuid Ó Giolláin, Locating Irish folklore, p. 158. See also, Alberto Maria Cirese, 'Gramsci's observations on folklore' in Anne Showstack Sassoon (ed.), Approaches to Gramsci (London, 1982), pp 212-47.

\section{Referenced cited}

Abbas, Hassan, The Taliban revival: violence and extremism on the Pakistan-Afghanistan frontier, New Haven, 2014. 
Barnham, Henry D., Tales of Nasr-ed-Din Khoja, London, 1923.

Borrow, G. H., The Turkish jester; or, The pleasantries of Cogia Nasr Eddin effendi, Ipswich, 1884.

Boyarin, Daniel, Border lines: the partition of Judaeo-Christianity, Philadelphia, 2004.

Cashman, Ray, Storytelling on the Northern Irish border: characters and community, Bloomington, IN, 2008.

Cerf, Bennett, Good for a laugh: a new collection of humorous tidbits and anecdotes from Aardvark to Zythum, London, 1953.

Cirese, Alberto Maria, 'Gramsci's observations on folklore' in Anne Showstack Sassoon (ed.), Approaches to Gramsci (London, 1982), pp 212-47.

Collins, Michael, Rail versus road in Ireland, 1900-2000: a century of change in Irish railways' road and rail passenger services and vehicles, Newtownards, 2000.

Denton, Gilbert and Fahy, Tony, The Northern Ireland land boundary, 192392, Belfast, 1993.

Donnan, Hastings and Wilson, Thomas M. (eds.), Border approaches: anthropological perspectives on frontiers, London, 1994.

Duffy, Patrick J., 'Continuity and change in the border landscapes' in Brian S. Turner (ed.), The Debatable land: Ireland's border counties, Downpatrick, 2002, pp 20-30.

Elwell-Sutton, L. P. 'Sufism and pseudo-Sufism' in Encounter, xliv, no. 5, 1975, pp 9-17.

Evans, Bryce, Ireland during the Second World War: farewell to Plato's Cave (Manchester, 2014).

Foster, Roy, W. B. Yeats, A Life, I: The Apprentice Mage 1865-1914, 2 vols, Oxford, 1997.

Freud, Sigmund, Jokes and their relation to the unconscious, London, 1960. Thongchai Winichakul, Siam mapped: a history of the geo-body of a nation, Honolulu, 1994.

Gallagher, Anita (ed.), Rinso Days and Rainbow Nights: Women's Lives in Glenfarne, Co. Leitrim 1920-1960, Manorhamilton, 2001. 
Girvin, Brian, 'The republicanisation of Irish society, 1932-48' in J. R. Hill (ed.), A new history of Ireland, vii: Ireland, 1921-84, Oxford, 2003, pp 127-60..

Graves, Robert, 'Introduction' in Idries Shah, The Sufis, London, 1964.

Harris, Rosemary, Prejudice and tolerance in Ulster: a study of neighbours and 'strangers' in a border community, Manchester, 1972.

Irwin, Robert, Memoirs of a Dervish: Sufis, mystics and the sixties, London, 2011.

Johnson, D. S. 'Cattle smuggling on the Irish border, 1932-8' in Irish economic and social history, xi (1979), pp 41-63.

Johnson, David, The interwar economy in Ireland, Dublin, 1985.

Kaufman, Asher, Contested frontiers in the Syria-Lebanon-Israel region: cartography, sovereignty, and conflict, Baltimore, 2014.

Leary, Peter, Unapproved routes: histories of the Irish border, 1922-72, Oxford, 2016.

Light, Alison, Common people: the history of an English family, London, 2014.

Luddy, Maria, 'The problem of equality: women's activist campaigns in Ireland, 1920-40' in Thomas E. Hachey (ed.), Turning points in twentieth-century Irish history, Dublin, 2011, pp 57-76.

Marzolph, Ulrich, 'Persian humour in the international context' in Ruse and wit: the humorous in Arabic, Persian, and Turkish narrative, Boston. Mass., 2012, pp 33-43.

Marzolph, Ulrich, 'Timur's humorous antagonist, Nasreddin Hoca' in Oriente Moderno, Ixxvi, no. 2, 1996, pp 485-98.

Nash, Catherine, Dennis, Lorraine and Graham, Brian, 'Putting the border in place: customs regulations in the making of the Irish border, 1921-45', Journal of historical geography, xxxvi, 2010, pp 421-31.

Ní Cheallaigh, Emer, “"The road that runs down by the border”: a study of smuggling in the oral tradition of Ireland' (M.Litt. thesis, University College Dublin, 2005).

Ó Giolláin, Diarmuid, 'Revisiting the holy well' in Éire-Ireland, xl, Spring/Summer 2005, pp 11-41. 
Ó Giolláin, Diarmuid, Locating Irish folklore: tradition, modernity, identity, Cork, 2000.

O'Leary, Brendan, 'Analysing partition: definition, classification and explanation', Political Geography, xxvi, 2007, pp 886-908.

Patterson, Henry, Ireland's violent frontier: the border and Anglo-Irish relations during the Troubles, Basingstoke, 2013.

Shah, Idries, The exploits of the incomparable Mulla Nasrudin, London, 1973.

Shah, Idries, The Sufis, London, 1964. 